MATRIK: JURNAL MANAJEMEN, STRATEGI BISNIS DAN KEWIRAUSAHAAN

Homepage: https://ojs.unud.ac.id/index.php/jmbk/index

Vol. 15 No. 1, Februari (2021), 137-145

\title{
Optimizing Iso 9001: 2015 Implementation with SWOT and QSPM Method
}

\author{
Chega Putri Pratiwi 1), Muji Gunarto ${ }^{2)}$ \\ 1,2) Universitas Bina Darma, Palembang \\ email: mgunarto@binadarma.ac.id
}

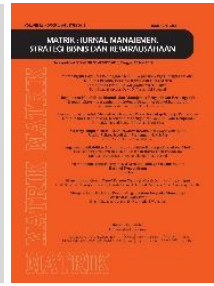

DOI : https://doi.org/10.24843/MATRIK:JMBK.2021.v15.i01.p12

\begin{abstract}
PT Saba Indomedika Jaya obtained results that indicate an indication of strategic initiatives that are still ineffective to be implemented in supporting the success of the process and requirements of the ISO 9001: 2015 clause in the 2018 and 2019 audits. Therefore, it is necessary to identify alternative strategies and determine priority strategies to optimize ISO 9001: 2015 at PT Saba Indomedika Jaya. The research method used is the descriptive qualitative method using SWOT analysis tools (Strengths, Weaknesses, Opportunities, and Threats) and QSPM (Quantitative Strategic Planning Matrix). There were 12 alternative strategies to optimize the ISO 9001: 2015 quality management system using the SWOT matrix (Strengths, Weaknesses, Opportunities, Threats). After going through three stages of strategic management planning that uses QSPM (Quantitative Strategic Planning Matrix) as a tool for selecting the main alternative strategy, the main strategy is obtained, which has the highest attractiveness value of 5.6619, namely creating a competency matrix and conducting training to reduce competency gaps. between employees.
\end{abstract}

Keyword: ISO 9001:2015; SWOT; QPSM

\section{Optimalisasi Implementasi Iso 9001:2015 dengan Metode SWOT Dan QSPM Matriks}

\begin{abstract}
ABSTRAK
PT Saba Indomedika Jaya, mendapatkan hasil yang menunjukkan adanya indikasi inisiatif strategi yang masih belum efektif untuk diterapkan dalam mendukung keberhasilan proses dan peryaratan klausul ISO 9001:2015 pada audit tahun 2018 dan 2019. Oleh karena itu, perlu adanya identifikasi alternatif strategi dan penentuan strategi prioritas untuk mengoptimalkan implementasi ISO 9001:2015 di PT Saba Indomedika Jaya. Metode penelitian yang digunakan adalah metode deskriptif kualitatif dengan menggunakan alat analisis SWOT (Strengths, Weaknesses, Opportunities, dan Threaths) dan QSPM (Quantitative Strategic Planning Matrix). Didapatkan 12 alternatif strategi dalam mengoptimalkan penerapan sistem manajemen mutu ISO 9001:2015 dengan menggunakan matriks SWOT (Strengths, Weaknesses, Opportunities, Threats). Setelah melalui tiga tahap perencanaan manajemen strategi yang menggunakan QSPM (Quantitative Strategic Planning Matrix) sebagai alat pemilihan alternatif strategi utama, maka didapatlah strategi utama yang mempunyai nilai daya tarik paling tinggi sebesar 5,6619, yaitu membuat matriks kompetensi dan melakukan pelatihan untuk mengurangi gap kompetensi antar karyawan.
\end{abstract}

Kata kunci: ISO 9001:2015; SWOT; QSPM

\section{INTRODUCTION}

PT Saba Indomedika Jaya is a medical equipment distributor company that was founded in 2005 in Palembang and is a sister company of PT Saba Indomedika located in Jakarta. PT Saba Indomedika Jaya has a vision to be the first choice of a leading diagnostic company by providing satisfactory service to customers in total. In order to realize this vision, PT Saba Indomedika Jaya is committed to establishing, implementing, maintaining and continuously 
improving the quality management system, including the processes required and their interactions in accordance with the ISO 9001:2015 standard.

A quality management system (QMS) is a set of documented procedures and standard practices for system management aimed at ensuring the conformity of a process and product (goods or service) to the needs of certain requirements determined by the customer and the organization (Gaspersz, 2008, p. 268). ISO 9000 series which is a requirement used in the implementation of an organization's quality management system. ISO 9000 series is not a product or service standard, but is a standard of an organization's management system which, if applied within the organization, will affect how the product or service is processed.

The International Organization for Standardization or better known as ISO is an international organization that is responsible for coordinating the preparation of new standards or revisions of existing ISO standards. The word ISO was chosen as the name of this organization because it stands for each different language (IOS in English, OIN in French for Organization Internationale de Normalisation, or MOS in Russian for Myezhdunarodnaya Organizatiya Po Standartizatsii) so the founders used the word ISO which came from from the Greek, "isos" which means the same (Witara, 2018, pp. 8-9). The latest version of the ISO standard is ISO 9001:2015. The ISO standards that have been set are reviewed every five years and revised if necessary to ensure that these standards can still be used as a useful "tool" for market developments and changing customer desires (Witara, 2018, p. 24).

Quality improvement carried out by PT Saba Indomedika Jaya through the implementation of ISO 9001:2015 since 2018 and has obtained an ISO 9001:2015 certificate in 2019 from the TUV Rheinland certification body. This shows the company's commitment to being able to meet customer requirements and customer satisfaction as well as being able to meet the applicable laws and regulations. During its implementation, PT Saba Indomedika Jaya has conducted 2 internal audits, namely in 2018 and 2019. From the results of internal audits conducted in 2018 and 2019 it shows that there is a decrease in audit findings for the nonconformance category but there is a significant increase in the findings category. observations so that there was an increase in the total findings from 2018 as many as 59 findings to 86 findings in 2019.

Decreased audit findings for the category of non-conformance findings (both major findings and minor findings) from 27 to 8 findings. This shows the company's commitment to being able to meet the requirements of the clauses in the ISO 9001:2015 quality management system standard. Meanwhile, an increase in the category of observation findings (both PNC findings, Potential Non-Conformity and OFI findings, Opportunity for Improvement) can indicate an indication of strategic initiatives from each internal and external situation in supporting the success of the process and requirements of the ISO 9001:2015 clause which there is still not effective to apply.

Observation findings are not a category of findings that violate the requirements of the ISO 9001:2015 clause, but rather there is a tendency for non-conformities to occur if improvements are not made to a system / process / procedure (PNC, Potential Non-Conformity) and are also suggestions for improvement to increase the effectiveness of the management system quality (OFI, Opportunity for Improvement) of each of the requirements of the ISO 9001:2015 clause. It was found that for the observation category (both PNC findings, Potential Non-Conformity and OFI findings, Opportunity for Improvement) in each ISO 9001:2015 clause there was an increase in findings from 2018 to 2019 namely in clauses 6, 7, 9, 10 for PNC and clauses 6, 7, 8, 10 for the OFI category. There needs to be an appropriate strategy in improving performance and improving the performance of each clause of ISO 9001:2015, especially those that have increased the number of findings (Majid, 2020).

It is important for any company or organization to determine a reliable strategy so that the previously set goals can be achieved (Hezarjribi \& Bozorgpour, 2017). David \& David, 
(2016, pp. 18-19) state that strategy is a common means or tool with long-term goals to be achieved. The same thing was also expressed by (Rangkuti, 2015, p. 3), strategy is defined as all efforts or methods taken to achieve goals both in the short and long term. Business strategy is the company's ability to analyze the company's external and internal environment in formulating (planning) strategies, implementing plans designed to achieve company goals, and conducting evaluations to get feedback in formulating future strategies.

SWOT can be used for planning alternative strategies while the QSPM matrix is used for determining priority strategies (Juniastuti et al., 2018; Putri et al., 2014). There are also studies that use the SWOT method (Justina, 2017; Rahayu \& Paays, 2017; Wiyono et al., 2019) and QSPM (Mahfud \& Mulyani, 2017; Sumiarsih et al., 2018; Ulum \& Ismanto, 2017) in analyzing implementation ISO 9001 quality management system that has been implemented.

SWOT stands for strengths, weaknesses, opportunities and threats (Sallis, 2012, p. 221). SWOT analysis is a strategic planning technique that is useful for evaluating internal factors (strengths and weaknesses) and external factors (opportunities and threats) of an organization.

Strengths are resource/capabilities that are controlled or available to a company that make the company relatively superior to its competitors in meeting customer needs. Weaknesses are limitations/deficiencies in one or more resources/capabilities of a company relative to its competitors that become obstacles in meeting customer needs effectively. Opportunities are favorable situations in a company's environment. Threats are unfavorable situations in a company's environment and become a barrier for the company in achieving the desired position.

Formulating a SWOT analysis for a company is done by taking advantage of opportunities, strengths, and reducing threats and weaknesses. SWOT analysis begins by comparing the external factors consisting of opportunities and threats with internal factors consisting of the company's strengths and weaknesses. In a study conducted by Justina, (2017), the results of the SWOT analysis obtained factors that can be the basis for the formation of a strategy to develop a quality management system and make it a developing and sustainable system.

The SWOT matrix is grouped into four types of strategies, namely: (1) S-O (StrengthsOpportunities) quadrant is a strategy that uses all the strengths we have to seize opportunities; (2) Quadrant W-O (Weaknesses-Opportunities) is a strategy that minimizes weaknesses to seize opportunities. This means that there are many opportunities that can be achieved, but are not supported by adequate strength, so that these weaknesses need to be minimized first; (3) Quadrant S-T (Strengths-Threats) is a strategy that is prepared by using all the strengths possessed to overcome threats that will occur; (4) Quadrant W-T (Weaknesses-Threats) is a strategy that is prepared by minimizing weaknesses to avoid existing threats (Rangkuti, 2015, p. 26).

In this study, the results of the SWOT analysis are in the form of alternative strategies which are then determined by the attractiveness value so that the main effective strategy is obtained to be applied using the QSPM matrix. The QSPM (Quantitative Strategic Planning Matrix) matrix is an analytical tool used to decide which strategy to use based on the attractiveness of several alternative strategies. QSPM calculation is based on input from internal external matrix weights, as well as alternative strategies at the matching stage.

\section{RESEARCH METHODS}

The research method used is descriptive qualitative method using SWOT and QSPM analysis tools conducted at PT Saba Indomedika Jaya, Palembang. The number of key informants in this study consisted of eight experts and practitioners taking into account their 
level of understanding, competence, and capacity. To get the data used the method of observation, interviews and filling out questionnaires. The data that has been collected needs to be processed first with the aim of summarizing the data collected from the results of interviews and filling out questionnaires by expert respondents and observations in the field.

The strategy formulation process is based on a three-stage strategy formulation framework consisting of data input, data matching, and decision-making stages. The data obtained from observations and interviews with key informants were analyzed descriptively to define the company's vision, mission and goals, a list of the company's external and internal environment, and the company's position in the industry. The existing data is then classified qualitatively according to the analysis of the external environment to find out opportunities and threats from the outside, then analyze the internal environment to determine the strengths and weaknesses within the company. A list of existing opportunities, threats, strengths, and weaknesses is evaluated and made in the form of External Factor Evaluation (EFE) and Internal Factor Evaluation (IFE) matrices.

After EFE and IFE matrix composed, then the next step is to combine the factors - external and internal factors for developing the company's strategic alternatives by clicking using IE matrix and SWOT matrix. Then the QSP M matrix is used to evaluate and choose the best strategy to be used from several alternative strategies (David \& David, 2016, pp. 266-269).

\section{RESULTS AND DISCUSSION}

The strategy formulation in this research first begins with identifying and analyzing the internal and external environment. After obtaining the internal strategic factors that affect PT Saba Indomedika Jaya, then weighting and ranking is carried out to find out how important internal and external factors are for the company and what is the rating of each of these variables. The assessment to determine the weight and rating is carried out using a questionnaire method filled out by predetermined key informants.

Table 1. Internal Factor Evaluation (IFE) Matrix

\begin{tabular}{|c|c|c|c|c|c|}
\hline \multicolumn{3}{|r|}{ Internal Strategic Factors } & \multirow{2}{*}{$\begin{array}{c}\text { Weight } \\
0,0507\end{array}$} & \multirow{2}{*}{$\begin{array}{c}\text { Rating } \\
3\end{array}$} & \multirow{2}{*}{$\begin{array}{c}\begin{array}{c}\text { Total } \\
\text { Score }\end{array} \\
0,1646\end{array}$} \\
\hline & 1 & Good HR development (competence matrix and training) & & & \\
\hline \multirow{9}{*}{ Strength } & 2 & $\begin{array}{l}\text { The existence of providing motivation / rewards (bonuses, } \\
\text { years of service, incentives) to employees }\end{array}$ & 0,0482 & 3 & 0,1566 \\
\hline & 3 & Management communication to employees has gone well & 0,0521 & 3 & 0,1629 \\
\hline & 4 & $\begin{array}{l}\text { The company's vision and mission are defined in a clear, } \\
\text { measurable and directed organizational strategy }\end{array}$ & 0,0530 & 3 & 0,1787 \\
\hline & 5 & $\begin{array}{l}\text { Have a company management system (ISO 9001:2015 } \\
\text { certificate) }\end{array}$ & 0,0510 & 4 & 0,1912 \\
\hline & 6 & $\begin{array}{l}\text { Complete range of products in } 5 \text { categories of medical } \\
\text { devices }\end{array}$ & 0,0487 & 4 & 0,1765 \\
\hline & 7 & Monthly monitoring of the budgeting process & 0,0503 & 3 & 0,1636 \\
\hline & 8 & $\begin{array}{l}\text { There is a clear procedure (process document) in carrying out } \\
\text { activities / activities }\end{array}$ & 0,0512 & 4 & 0,1790 \\
\hline & 9 & $\begin{array}{l}\text { Product quality according to customer requirements } \\
\text { kebutuhan }\end{array}$ & 0,0535 & 4 & 0,1871 \\
\hline & 10 & $\begin{array}{l}\text { Have a strong commitment in providing a fast response to } \\
\text { customers in after sales service }\end{array}$ & 0,0492 & 4 & 0,1721 \\
\hline \multirow[t]{2}{*}{ Weakness } & 1 & $\begin{array}{l}\text { Corporate cultural values have not been campaigned } \\
\text { optimally }\end{array}$ & 0,0444 & 3 & 0,1110 \\
\hline & 2 & There is no marketing research function (main center) & 0,0461 & 3 & 0,1382 \\
\hline
\end{tabular}




\begin{tabular}{lllll}
\hline 3 & Unequal Quality Of Human Resources & 0,0520 & 2 & 0,1104 \\
\hline 4 & The company's reputation is not well known & 0,0487 & 3 & 0,1278 \\
\hline 5 & Has a limited distribution network in the South Sumatra area & 0,0449 & 3 & 0,1459 \\
\hline 6 & $\begin{array}{l}\text { Management of company assets (trading assets and non- } \\
\text { trading assets) is still not good }\end{array}$ & 0,0513 & 2 & 0,1219 \\
\hline 7 & $\begin{array}{l}\text { Forecast is still not optimal so there is a buildup of stock and } \\
\text { vacancies }\end{array}$ & 0,0523 & 2 & 0,1177 \\
\hline 8 & $\begin{array}{l}\text { There are still many administrative processes that are done } \\
\text { manually }\end{array}$ & 0,0500 & 3 & 0,1375 \\
\hline 9 & $\begin{array}{l}\text { Corporate Social Responsibility is not yet stable and } \\
\text { sustainable }\end{array}$ & 0,0482 & 3 & 0,1265 \\
\hline 10 & $\begin{array}{l}\text { The follow-up monitoring process for meeting results is still } \\
\text { not optimal meeting }\end{array}$ & 0,0544 & 3 & 0,1361 \\
\hline
\end{tabular}

Source : Analysis Results, 2020

Table 2. Matrix Ex ternal Factor Evaluation (EFE)

\begin{tabular}{|c|c|c|c|c|c|}
\hline \multicolumn{3}{|r|}{ External Strategic Factors } & Weight & Rating & Total \\
\hline \multirow[t]{10}{*}{ Opportunity } & 1 & Increased sales of Rapid Test & 0,0529 & 3 & 0,1785 \\
\hline & 2 & Good relationship with principal & 0,0517 & 4 & 0,1809 \\
\hline & 3 & There is good cooperation with waste management & 0,0474 & 3 & 0,1362 \\
\hline & 4 & $\begin{array}{l}\text { Being the only distributor in South Sumatra that markets } \\
\text { Integrated Business Solution (IBS) }\end{array}$ & 0,0531 & 3 & 0,1792 \\
\hline & 5 & The increasing index of customer satisfaction and loyalty & 0,0568 & 4 & 0,2058 \\
\hline & 6 & $\begin{array}{l}\text { Improve company image by standardizing the distribution } \\
\text { system according to government regulations (CDAKB - } \\
\text { Permenkes No. } 4 \text { of 2014) }\end{array}$ & 0,0537 & 3 & 0,1813 \\
\hline & 7 & Have a complete license as a distributor of medical devices & 0,0588 & 4 & 0,2206 \\
\hline & 8 & $\begin{array}{l}\text { Have an i-care application that makes it easier for } \\
\text { customers to provide complaints and input to the company }\end{array}$ & 0,0568 & 3 & 0,1916 \\
\hline & 9 & $\begin{array}{l}\text { Government Regulation on procurement system through } \\
\text { e-catalog }\end{array}$ & 0,0570 & 3 & 0,1852 \\
\hline & 10 & There are workshops and seminars for customers & 0,0543 & 3 & 0,1834 \\
\hline \multirow[t]{9}{*}{ Threats } & 1 & Rupiah exchange rate fluctuations & 0,0547 & 3 & 0,1505 \\
\hline & 2 & BPP is still dominated by 1 Principal & 0,0543 & 2 & 0,1222 \\
\hline & 3 & Overdue aging that disrupts the company's cash flow & 0,0617 & 2 & 0,1079 \\
\hline & 4 & $\begin{array}{l}\text { KSO investment that continues to grow and does not } \\
\text { match the expected reagent utilization }\end{array}$ & 0,0596 & 2 & 0,1193 \\
\hline & 5 & The decline in MCU patients & 0,0570 & 3 & 0,1496 \\
\hline & 6 & $\begin{array}{l}\text { Expedition limitations in distributing goods in several } \\
\text { areas }\end{array}$ & 0,0543 & 3 & 0,1494 \\
\hline & 7 & $\begin{array}{l}\text { The level of competition with competitors is getting } \\
\text { tougher }\end{array}$ & 0,0578 & 2 & 0,1373 \\
\hline & 8 & Regulatory changes (IPAK, CDAKB) & 0,0580 & 3 & 0,1595 \\
\hline & & Total & 1,0000 & & 2,9386 \\
\hline
\end{tabular}

Source : Analysis Results, 2020

From the data on the weighting and ranking of strategic factors, the total IFE value is 3.0054 and the total EFE value is 2.9386. Then these two factor evaluation values are plotted in the IE matrix quadrant which can be seen in the image below: 


\begin{tabular}{|c|c|c|c|}
\hline IFE & $\begin{array}{c}\text { Strength } \\
(3.00-4.00) \\
\text { EFE }\end{array}$ & $\begin{array}{c}\text { Midle } \\
(2.00-2.99)\end{array}$ & $\begin{array}{c}\text { Low } \\
(1.00-1.99)\end{array}$ \\
\hline $\begin{array}{c}\text { Strength } \\
(3.00-4.00)\end{array}$ & $\begin{array}{c}\text { I } \\
\text { Grow and Build }\end{array}$ & $\begin{array}{c}\text { II } \\
\text { Grow and Build }\end{array}$ & $\begin{array}{c}\text { III } \\
\text { Hold and } \\
\text { Maintain }\end{array}$ \\
\hline 2,9386 & IV & $\begin{array}{c}\text { V } \\
\text { Mold and } \\
(2.00-2.99)\end{array}$ & $\begin{array}{c}\text { Maintain } \\
\text { Harvest and } \\
\text { Divest }\end{array}$ \\
\hline $\begin{array}{c}\text { Gow } \\
(1.00-1.99)\end{array}$ & $\begin{array}{c}\text { Hold and } \\
\text { Maintain }\end{array}$ & $\begin{array}{c}\text { Harvest and } \\
\text { Divest }\end{array}$ & $\begin{array}{c}\text { Harvest and } \\
\text { Divest }\end{array}$ \\
\hline
\end{tabular}

Gambar 1. Matriks IE

Sumber: Analysis Results, 2020

The results of matching with the IE matrix show that PT Saba Indomedika Jaya is currently in quadrant IV position, which shows the strategy needed for the company at this time is grow and build strategy. Grow and build strategy shows that the company needs a strategy to grow better and can develop the company to be even better.

\begin{tabular}{|c|c|c|}
\hline Eksternal & $\begin{array}{c}\text { Strengths } \\
\text { (Kekuatan) }\end{array}$ & $\begin{array}{l}\text { Weaknesses } \\
\text { (Kelemahan) }\end{array}$ \\
\hline & Strategi SO & Strategi WO \\
\hline $\begin{array}{c}\text { Opportunities } \\
\text { (Peluang) }\end{array}$ & $\begin{array}{l}\text { 1. Conduct a study on the possibility of } \\
\text { expanding the scope of business (adding new } \\
\text { RO and Principal) (S6, S9, S10, O1,04,05,07) } \\
\text { 2. Maintaining customer satisfaction by } \\
\text { providing continuous scientific education (S4, } \\
\text { S9, O5, 07, 010) } \\
\text { 3. Conduct socialization to customers and related } \\
\text { departments regarding product updates that } \\
\text { have been registered in the e-catalog and } \\
\text { changes to regulations/permits applied (S5, } \\
\text { S6, S9, O6, O7, O9) }\end{array}$ & $\begin{array}{l}\text { 1. Create a competency matrix and conduct } \\
\text { training to reduce competency gaps (W2, W3, } \\
\text { O5, O10) } \\
\text { 2. Creation of applications for digitizing process } \\
\text { documents (W6, W8, W10, O8) } \\
\text { 3. Make analysis of forecast calculations } \\
\text { together with related departments every month } \\
\text { and evaluate forecast results (goods } \\
\text { approaching expiration) periodically (W2, } \\
\text { W7, O1, O5, O9) }\end{array}$ \\
\hline \multirow[b]{2}{*}{$\begin{array}{c}\text { Threats } \\
\text { (Ancaman) }\end{array}$} & Strategi ST & Strategi WT \\
\hline & $\begin{array}{l}\text { 1. Monitoring and providing credit limits to } \\
\text { customers (S9, S10, T1, T3, T4, T5) } \\
\text { 2. Obtain CDAKB certificate and maintain ISO } \\
\text { 9001:2015 certificate (S1, S3, S4, S5, S8, T7, } \\
\text { T8) } \\
\text { 3. Scheduling planned visits, maintenance of tools, } \\
\text { calibration of tools on a regular basis (S10, T7) }\end{array}$ & $\begin{array}{l}\text { 1. Optimizing } \\
\text { marketing/event/sponsorship/entertain activities } \\
\text { (W4, W5, W9, T7) } \\
\text { 2. Perform asset audits on customers and employees } \\
\text { periodically (W6, T4) } \\
\text { 3. Improve the competence (product knowledge and } \\
\text { soft skills) of sales employees to increase sales } \\
\text { value (W3, W4, W5, T2, T4, T5, T7) }\end{array}$ \\
\hline
\end{tabular}

Figure 2. SWOT Matrix

Source : Analysis Results , 2020 
To produce several alternative strategies obtained from internal and external variables according to the company's position in the IE matrix, namely the grow and build strategy, the SWOT matrix was used in this study (Evelyn, 2018). In formulating a strategy that is right on target and allows it to be implemented, discussions are held with key informants who have experience in determining strategies by considering the previously defined strengths, weaknesses, opportunities, and threats.

The last stage of strategy formulation is the selection of an appropriate strategy that can be carried out by the company. The QSPM matrix allows to evaluate several alternative strategies obtained from the previously defined SWOT matrix. The assessment of the QSPM matrix was carried out through interviews and discussions with key informants in order to obtain a good strategy to be applied and in accordance with the current conditions of PT Saba Indomedika Jaya.

Table 3. QSPM Matrix

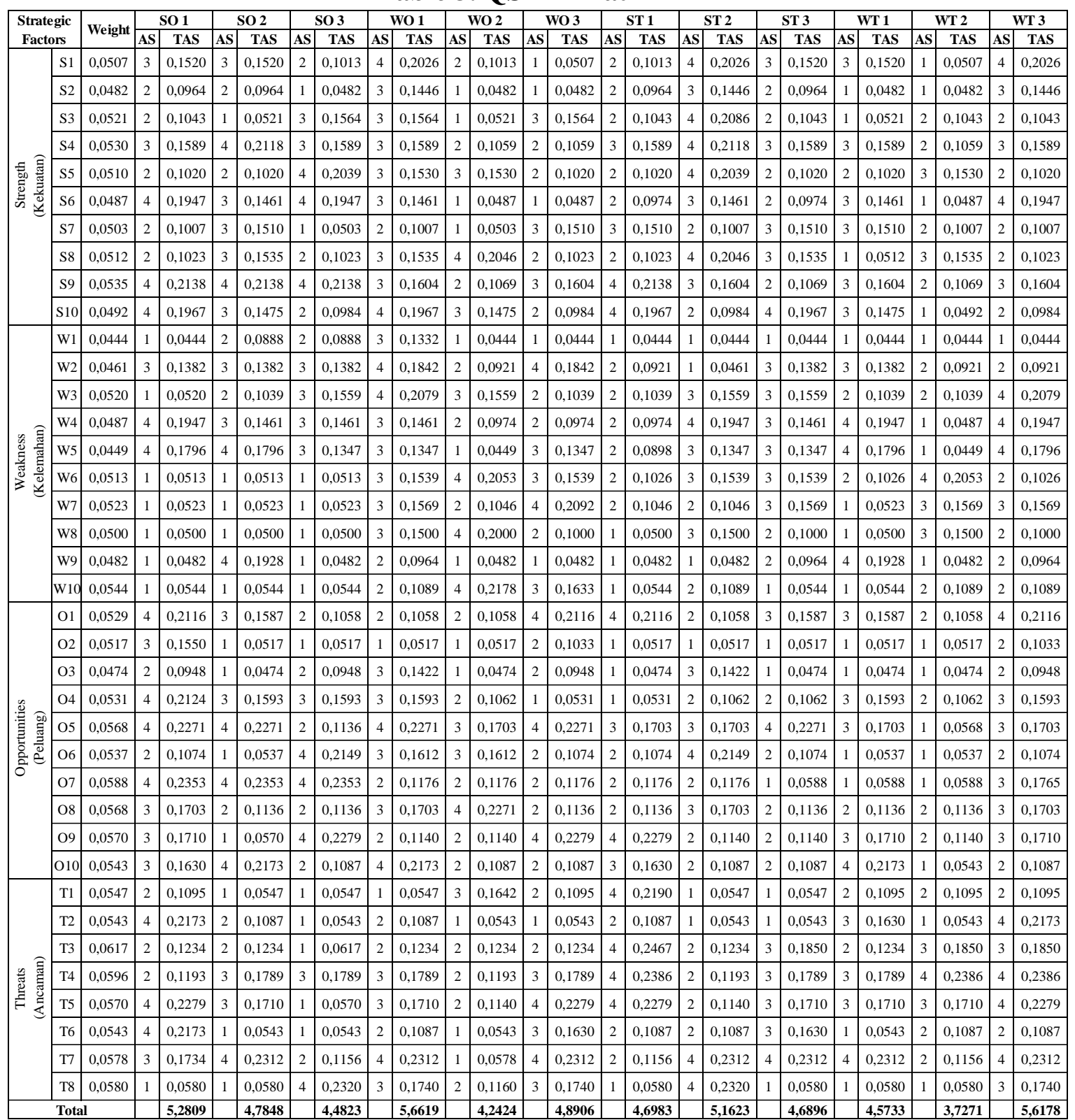

Source : Analysis Results , 2020 
An attractiveness score (AS) is assigned to each strategy to indicate the relative attractiveness of one strategy over another. The attractiveness scores (AS) applied to the QSPM matrix in this study are: $1=$ inappropriate strategy; $2=$ less appropriate strategy; $3=$ strategies that may be appropriate; $4=$ a very suitable strategy. Then this AS score is multiplied by the weight of each internal and external strategic factor. The alternative strategy that gets the highest total attractiveness score indicates that the strategy is the most attractive strategy to implement.

The following are 4 alternative strategies that have the highest score out of 12 alternative strategies, namely: (1) WO1 = Create a competency matrix and conduct training to reduce competency gaps; (2) WT3 = Improving the competence (product knowledge and softskill ) of sales employees to increase sales value ; (3) SO1 = Conducting a study on the possibility of expanding the scope of business (adding new RO and Principal); (4) ST2 = Obtain CDAKB certificate and maintain ISO 9001:2015 certificate. Alternative strategies have the highest total appeal is a strategy WO1 ( $\mathrm{m}$ arouses matrix of competencies and training to reduce the gap competence ) for a total value of 5.6619 appeal.

This strategy is expected to be a solution in optimizing the implementation of ISO 9001:2015 at PT Saba Indomedika Jaya, especially for the requirements of clause 7 (support) which experienced an increase in the number of findings compared to the previous year. This increase in employee competence can further facilitate the improvement of the quality management system so that the company's vision, mission, and goals are achieved in accordance with the targets that have been set.

\section{CONCLUSION}

The results of the research that have been carried out, it was found that the strategic position of PT Saba Indomedika Jaya which was analyzed using the internal external matrix (IE) was in quadrant IV position, namely grow and build. This shows that the company needs a strategy to grow and be able to develop the company for the better. Based on the analysis using the SWOT matrix (Strengths, Weaknesses, Opportunities, Threats) there are 12 alternative strategies in optimizing the implementation of the ISO 9001:2015 quality management system. $\mathrm{M}$ arouses matrix of competencies and training to reduce the gap between employee competence is a key strategy that has the highest value of the attractiveness of 5.6619 in the use QSPM (Quantitative Strategic Planning Matrix) as an alternative selection key strategies.

This research was conducted according to the company's current conditions so that if there are changes in the strategic environmental factors, both internal and external, the SWOT, weighting, and assessment factors in the study will also change so that there will be a change in strategy for the company. It is advisable for the company to conduct strategy formulation regularly (eg once a year) to get an up-to-date picture of the internal and external environment. And for further research, it is better to be able to continue the research to the strategy evaluation stage, because this research was carried out up to the analysis of the main strategy selection using QSPM

\section{REFERENCE}

David, F. R., \& David, F. R. (2016). Strategic Management: A Competitive Advantage Approach, Concepts \& Cases (Sixteenth). Pearson Education Limited. https://doi.org/10.1108/09596111111129977 
Evelyn. (2018). ANALISIS MANAJEMEN STRATEGI BERSAING DENGAN MATRIKS IE, MATRIKS SWOT DAN MATRIKS QSPM PADA PT. XYZ. JURNAL MANAJEMEN BISNIS DAN KEWIRAUSAHAAN, 02(4), 99-106. https://doi.org/10.24912/jmbk.v2i4.4869

Gaspersz, V. (2008). Total Quality Management. PT Gramedia Pustaka Utama.

Hezarjribi, H. N., \& Bozorgpour, Z. (2017). Optimized Business Management by Using SWOT and QSPM Matrices (Case Study: Mazandaran Wood and Paper Industries) H.N. Journal of Administrative Management, Education and Training, 13(1), 409-422.

Juniastuti, A., Falatehan, A. F., \& Muljono, P. (2018). The Strategy of Content Quality Improvement for E-Learning on Budget and Treasury Training Center. Jurnal Manajemen Pembangunan Daerah, 10(2), 18-32. https://doi.org/https://doi.org/10.29244/jurnal_mpd.v10i2.27791

Justina, D. (2017). Analisis Swot Dalam Pengembangan Sistem Manajemen Mutu Iso 9001 Pada Badan Pengelolaan Pajak Daerah Kabupaten Xyz Propinsi Sumatera. SUSTAINABLE COMPETITIVE ADVANTAGE-7 (SCA-7) FEB UNSOED, 7, 675-681.

Mahfud, T., \& Mulyani, Y. (2017). Aplikasi Metode QSPM ( Quantitative Strategic Planning Matrix ). Jurnal Sosisal Humanioradan Pendidikan, 1(1), 66-76.

Majid, N. (2020). Optimalisasi Kinerja Lembaga Amil Zakat Melalui Standar Mutu Iso 900. Filantropi: Jurnal Manajemen Zakat Dan Wakaf, 1(1), 69-87. http://ejournal.iainsurakarta.ac.id/index.php/filantropi/article/view/2366

Putri, N. E., Astuti, R., \& Putri, S. A. (2014). Perencanaan Strategi Pengembangan Restoran Menggunakan Analisis SWOT dan Metode QSPM (Quantitative Strategic Planning Matriks) (Studi Kasus Restoran Big Burger Malang). Jurnal Industria, 3(2), 93-106.

Rahayu, G. H. N. N., \& Paays, A. (2017). Analisis Efektifitas Penerapan Sistem Manajemen Terintegrasi (ISO 9001: 2008 , ISO 14001: 2014 DAN OHSAS 18001: 2007) di PT. ABC. Jurnal Manajemen Dan Bisnis (Performa), 14(2), 163-176.

Rangkuti, F. (2015). Analisis SWOT Teknik Membedah Kasus Bisnis. Gramedia Pustaka Utama.

Sallis, E. (2012). Total Quality Management in Education: Manajemen Mutu Pendidikan. IRCiSoD.

Sumiarsih, N. M., Legono, D., \& Kodoatie, R. J. (2018). Strategic Sustainable Management for Water Transmission System: A SWOT-QSPM Analysis. Journal of the Civil Engineering Forum, 4(1), 29-40. https://doi.org/10.22146/jcef.30234

Ulum, M., \& Ismanto, B. (2017). Strategi Peningkatan Mutu Sekolah Menengah Kejuruan Pasca Penerapan Sistem Manajemen Mutu ISO 9001:2008. Jurnal Pendidikan Ilmu Sosial, 1(1), 69-91.

Witara, K. (2018). Cara Singkat Memahami Sistem Manajemen Mutu ISO 9001:2015 dan Implementasinya. CV Jejak.

Wiyono, G., Welsa, H., \& Prayekti. (2019). Swot Dan Analytic Hierarchy Process Sebagai Acuan Strategi Optimasi Student Body. Jurnal Riset Bisnis Dan Manajemen, 12(1), 1-8. 